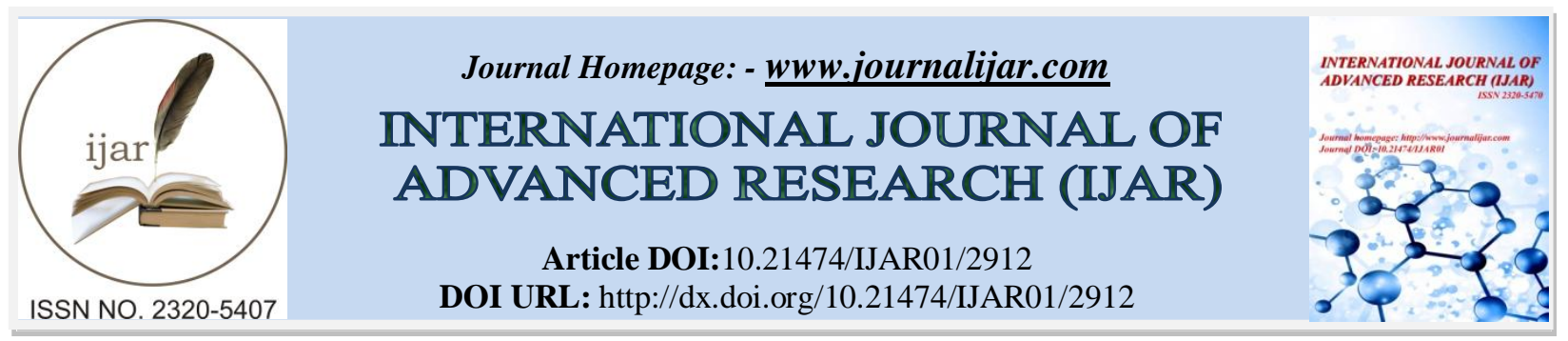

RESEARCH ARTICLE

\title{
EVALUATION OF GREEN AREAS ACCORDING TO THE DETERMINANTS OF URBAN BENEFITS AND, REFLECTION UPON “GREEN AREA STANDARDS"
}

Sema Karaguler

\section{Manuscript Info}

Manuscript History

Received: 24 November 2016

Final Accepted: 25 December 2016

Published: January 2017

Key words:-

green areas, green areas per

capita, green area standards, urban

planning, green urban areas, urban greenery.

\section{Abstract}

Energy consumption that will affect our future is highly related to green areas in urban and the environment. Green areas have the qualities to reduce the energy consumption of cities as well as buildings. Therefore, green areas now are taking over much more missions than ever before.

In this paper, a different calculation method as "effecting green area"has been introduced depending on coefficients of different qualified green area groups according to their performances. This method is not determined new green area standard value, just put on reducing the green areas sizes as temporarily by purposing more efficiency on urban benefits.

Copy Right, IJAR, 2016,. All rights reserved.

\section{Introduction:- The Importance of Green Area Planning}

Energy consumption is the main subject that will affect the future of our World. International Energy Agency (IEA) declares that buildings are responsible for at least $\% 40$ of the primary energy consumption and $\% 24$ of the global carbon dioxide emission of the world (Mira, 2013).

In cities, building masses constitute the main part of the areas that we are settled. It is obviously true that each one of these building masses is an energy consumption source. That is the reason why as the masses increase, the energy consumption increases.

However, due to needs of civilisation, each day the need for these building masses is getting inevitable. Consequently, the subject of decreasing the energy consumption of building masses is getting more and more important.

As the result, the concept of decreasing the energy consumption by increasing the relation of building masses with nature is maturing.

This new concept is an economic and sustainable approach in harmony with nature.

This way of thinking diverts the architects and city planners to pay much more attention to the importance of sustainable architecture and urbanism and especially to the effect of plants on city life. "Green architecture," "roof gardens," "green terraces," "vertical vegetation, etc. are designing approaches which are all included in the concept of "sustainability". They are designings implying that the plants placed on buildings show that inside or around the cities the tendency to green is relatively increasing. Today, the effects of green terraces and green roofs decreasing the energy consumption regarding heat losses for buildings and indirectly for the cities are plainly noticed. For example, the importance of green on the building, reducing the value of the heat conduction coefficient of the 
building envelope that is very effective on the construction of the energy efficient buildings is very often agreed upon (Voss, 213). In the same way, the positive effect of the green covered areas both on cities and surroundings in reaching the various objectives in lessening energy consumption can not be ignored. Various scientific works prove that these above mentioned positive effects are correct. The mentioned objectives are reducing noise, controlling of the wind and solar radiation and removing the environmental and visual pollution. Also, various positive effects of areas with green structures on the psyche- social subjects are very well known and accepted (Lyle, 1985).

All these developments show that the amount of green spaces in the city, open areas and providing the necessary standard of green area per capita are getting more and more important. That is why we may conclude that more detailed investigations must be made on this subject.

\section{Performance of Green Area Standards in Planning:-}

The distribution of the green areas in and around the cities depend on one single standard value as the quantity of green area per person; at during preparation phase of the development plans. Not taking into consideration the functions and the qualifications at all, the area sizes are added up on each other on the $\mathrm{m}^{2}$ basis and then the total is divided by the population of the city and as the result, the green area per person is obtained. The obtained amount of green area per person is checked by how much it is in compliance with the green area standards to be followed in urbanism discipline (Karagüler, 1983). In this respect, these are three critical issues that may be considered as problems that need attention:

1. Green area standards applications in our World differs from $2 \mathrm{~m}^{2} /$ person to $80 \mathrm{~m}^{2} /$ person. This huge variation in value causes and unprevented chaos. Consequently, the acceptable standard value of needed green area becomes flue and a standard value that can be accepted as satisfactory can not be obtained (Y1ldizc1, 1982).

2. The distribution of green spaces in and surroundings of the cities follow a special hierarchy. A city may be rich in mountainous, rough, historical and /or archaeological conditions. In this case, the distribution mentioned above, can not often be provided especially in the cities developing from the past till today.

3. Green areas with various functions have various factorial values like "The amount of green surfaces", "usability" etc. The problem is that these different values of green areas have not been evaluated regarding benefits to the city and have not been reflected in planning.

The sufficiency of green areas in the development plan, regarding all the benefits of them to the cities, especially energy control can be clarified by solutions of these three issues.

The required standard of the first subject can be determined by taking the city groups in the World showing common standards into consideration. That determination can only be done by the decisions and certain assumptions of city planners by examining the economic, geographical and social specialities of the planning area (Karagüler, 2004). However, the solution requires a detailed evaluation.

As the second issue, even if the total green area is numerically suitable to the determined standard; the distribution in the city and around may not be planned as hierarchical. This problem can be solved again by city planners; taking city planning discipline as the main concept and regarding the developing tendency of the planned area by giving priority to green area hierarchy and can only be solved by a conscious planning.

The third important point is; even if a proper planning has been done for the first and second points; the planned green facilities may not be evaluated and calculated considering green area performance. In other words, even if a standard is provided and a green hierarchy system is built up at the planned area; the planned green areas may not be evaluated regarding the usefulness of the green area effectiveness to the city. The solution to this subject will be explained in this article, by proposing an effective green area evaluating method.

\section{Effective Green Area Method:-}

The approach mentioned above will be explained by proposing the "Effective Green Area Method." This method depends on reducement of green area bignesses to effective green area bignesses. The "Effective Green Area" concept will be explained at below. Following the explanation, the phases of the method will be put forward for consideration. 


\section{Effective Green Area Concept:-}

When the subject is considered in regards to the effectiveness of the green areas, have quite a lot in number and various benefits. The characteristics of these areas change by the effects of various factors. As very well known, because of their qualifications, the green areas on the plan may be as big as other green areas; but may not perform the same green area performances. The distinction of active and passive green areas is not satisfactory necessarily to reveal these different performances. Some active green areas are closed to public like building gardens. In the same way, some passive green areas are closed public because of their different statuses like Consulate gardens or military green areas although they have intensity green tissued. Usability of green area is so important as well. So, the subject is the benefit of cities from the green areas; the main reason of this matter may be explained by two factors. These factors must be the quantity of planted surfaces in the green areas (Schipperijn et al. 2010a) and the public ownership. Therefore, the effect of some subfactors determined by the mentioned two main factors should be reflected in city planning to show out the effectiveness of the green area species. The samples of green areas with different quantity of green tissued areas are illustrated in figure 1 and 2. In this respect, we may determine ratios considering the effects of the factors mentioned above. These ratios are multiplied by the sum of green areas, and new area bignesses are obtained. They should be considered as effective green area values. In this respect, the control of the standard of green area per person should be made by using effective green areas.

Consequently, this article defends that; in city planning, the calculation of effective green areas should be done according to the main factors determining the benefits of green areas In cities. Then it is emphasised that green areas should be evaluated by considering their suitability degree to the mentioned main factors and then calculated regarding the effective green area values. In other words, the article claims that at first the bignesses of areas having green area status on the plan must be reduced to different values considering green performance and then their appropriateness to the standard should be controlled (Figure 1 and Figure 2).

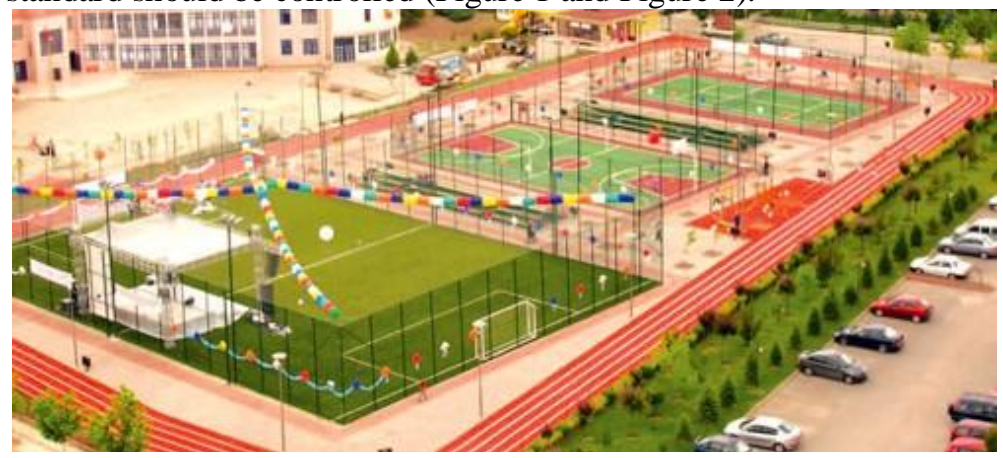

Figure 1:- Poor Vegetated Green Areas Examples From Istanbul.

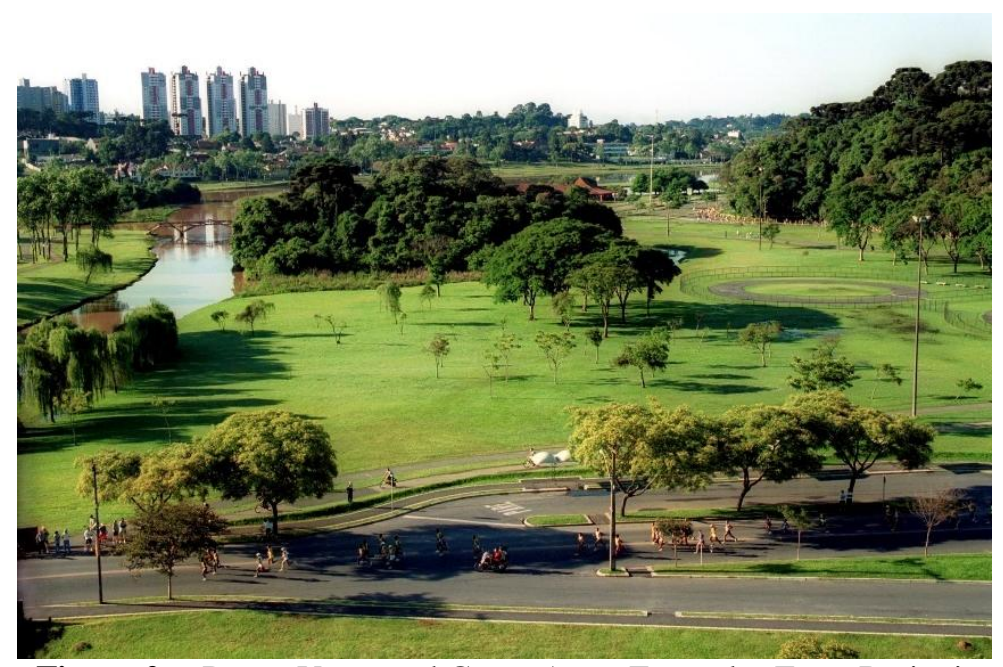

Figure 2:- Dense Vegetated Green Areas Examples From Barigui.

The Stages of Effective Green Area Method:-

The method contains the following steps in succession: 
1. Determination of green area types

2. Determination of positive factor numbers

3. Determination of green efficiency coefficients

4. Determination of green area sizes

Figure 3 shows the "Flowing Scheme of the Effective Green Area Method" prepared in compliance with the steps mentioned above.

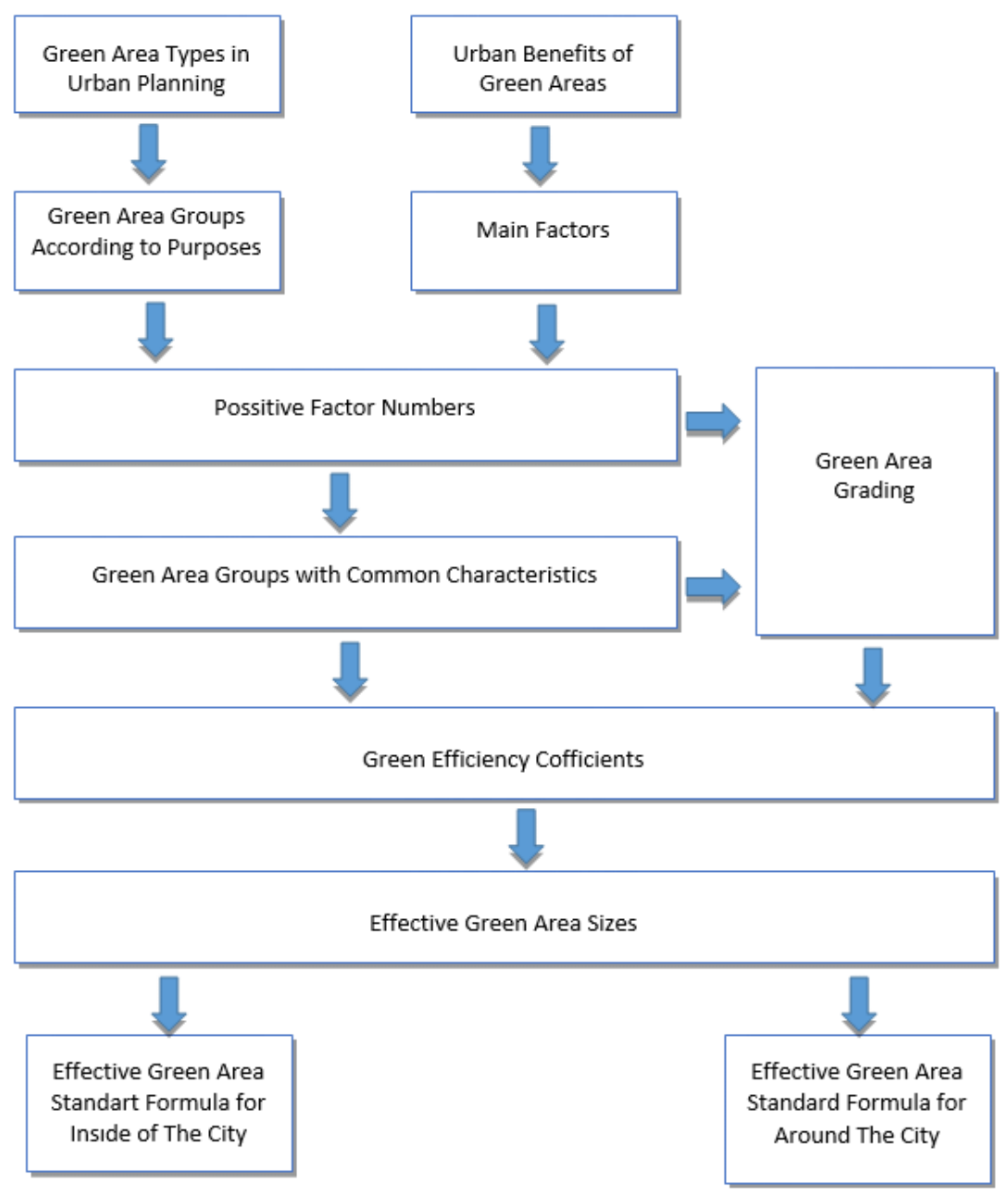

Figure 3:- Flowing Scheme of the Effective Green Area Method.

\section{Determination of Green Area Types and Positive Factor Numbers:-}

Green areas have various functions in respect with usage aims of their times. The aims depend on upon the visiting reasons of the time (Schipperijn et al. 2010b). For that reasons, the green areas in and around the city can be grouped in functions in compliance with today's objectives as follows:

1. Green areas for resting purposes

2. Green areas for gardening use

3. Green areas for sports and play facilities

4. Green areas for entertaining purposes

5. Green areas for agricultural purposes

6. Green areas with spatial status

During the determination of six main groups, the existing groupings are taken into consideration with literature and discipline subjects and also, new groups are added to the present day's conditions (Çetiner, 1979), (Öztürk, 2004), (Germann and Seeland, 2002). 
The green area types forming the above-mentioned main groups are shown in Table 1.

Table 1:- Factor Numbers for Green Spaces.

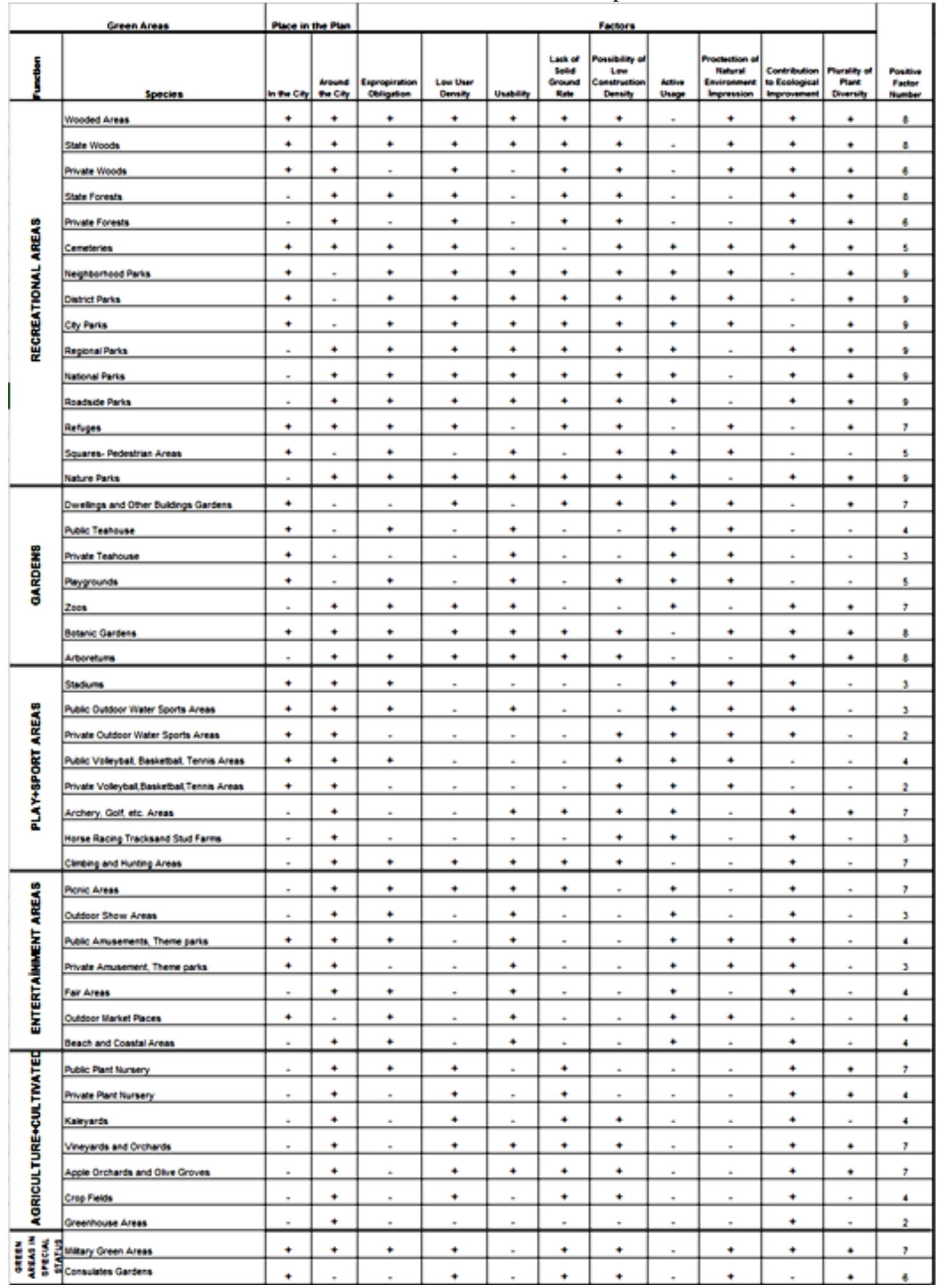


The main factors that will determine the suitability degrees of the green area types can be presented in relation to the environmental and urban benefits of the green areas.

Today, the environmental and urban benefits of the green areas may be listed briefly as follows:

1. Protection of ecological balance

2. Control of the solar radiation and wind

3. Prevention of environmental pollution (air, visual, noise, etc.)

4. Control of natural disasters (flood, erosion, earthquake, etc.)

5. Fulfillment of open air social activities

6. Providing of psychological satisfaction ( improvement of mental health, rest, touristic actions, getting in close touch with nature, focusing on human scale) (Schipperijn et al. 2010b), (Karagüler, 1993)

These benefits such as protection of ecological balance, control of the wind and solar radiation, prevention of environmental pollution and control of natural causes can only be provided at green areas with intense green tissue. Environmental and urban benefits directed towards psychological satisfaction such as resting, getting close to nature, focusing on human scale and improvement of mental health; can be provided if the use of the green is open for public use and concentrated green tissue. Taking these evaluations into consideration, the factors affecting the values such as the concentration of green tissue on green areas and being open to public use only be determined by the main effective factors provide the urban and environmental benefits of green areas. Green tissue concentration on green areas varies according to factors mentioned below:

1. The amount of construction

2. The ratio of hard ground

3. Density of users

4. Diversity of plants

5. Difference of plant sizes

6. Preservation of natural surrounding impression

The use of green areas open to public change in respect to three main factors mentioned below:

1. Being in possession of public

2. Usability

3. Being active

On this green space if the amount of construction and ratio of the hard ground is plenty the areas covered with green tissue will be accordingly small. On the other hand, as the user density gets higher, it will become harder and harder to keep the ratio of green tissue high. The increase in the diversity of plants and difference of plant sizes depend on the highness of the concentration of green tissue. Therefore, these factors may be accepted as the main factors of protection of ecological balance, improvement of urban climate, contribution to urban landscape and prevention of noise in the achievement of urban and environmental benefits of green spaces. While arranging the green areas using natural and especially materials and objects made of plants increase the density of green. At the same time, it plays a very efficient role in providing all the benefits of psychological satisfaction because it was not disturbing the impression of natural atmosphere and characteristic. On the other hand, urban citizens can only use this green area type if the ownership belongs to the public. The usage of private and judicial owned green areas is very limited because they do not belong to the public. Areas like pedestrian refuges, military green areas and small woods belonging to the foreign country representatives have special statuses and special place in the planning area. For those reasons, these green areas are closed to direct public use, and this plainly shows the importance of the "usability" factor.

Considering the analyses mentioned above the nine main factors that are listed below can be determined in providing urban and environmental benefits for green area types:

1. Expropriation obligation

2. Usability

3. Lack of "solid ground rate."

4. Possibility of low-density construction

5. Low user density

6. Active usage

7. Plurality of diversity of plants 
8. Variety of plant heights

9. Protection of natural environment impression

"Positive Factor Numbers" are determined by evaluating the appropriateness of these factors to each green area type. In this case, green areas can be categorised gradually in respect to positive factor numbers as shown in Table 1.

\section{Determination of Green Efficiency Coefficient for Green Areas:-}

In planning, it has been considered necessary that green area types in and around the city should be classified into two main groups as shown in Table 1 (Ratcliffe, 1974). Considering the determined factors and positive factor numbers as mentioned in the second section; green area types in and around the cities show common green area characteristics forming different groups of green area types. For this reason, the green area types are grouped considering the common features ( see Table 2 and 3). In another study, starting from the biggest to the fewest, a green area grouping with different percentages is prepared as good, moderate, poor and barren (Wang et al. 2014).In this mentioned study green area categorisation is made using the filtering percentages of green tissues and depending on the water filtering capacity. At the result, the importance of covered with plants is emphasized. In this article, priority is given to spaces covered with plants while classifying the groups. However, also, other factors determining the benefits of the green areas to the cities explained in chapters 3,2 and 1. are taken into consideration. In each one of the green areas groups with common characteristics formed by this method, the positive factor numbers of the green area types will be equal or very close to equal.

Table 2:- Efficiency Percentage of Green Areas in the City.

\begin{tabular}{|c|c|c|c|c|c|c|c|c|c|c|}
\hline & OUAUTY & GREEM AREAS II THE CITY & $\begin{array}{l}\text { mTHAN } \\
\text { STAMDART }\end{array}$ & $\begin{array}{c}\text { COOE } \\
100\end{array}$ & $\begin{array}{l}\text { POSTINE } \\
\text { FACTOR } \\
\text { NUMBER }\end{array}$ & $\begin{array}{l}\text { L. DEGREF } \\
\text { GRFEN } \\
\text { AREAS }\end{array}$ & $\begin{array}{l}\text { IL DEGREI } \\
\text { GRYFA } \\
\text { AREAS }\end{array}$ & $\begin{array}{l}\text { I. DEGREF } \\
\text { GREFW } \\
\text { AREAS }\end{array}$ & $\begin{array}{l}\text { N. DEGREI } \\
\text { GREFA } \\
\text { AREAS }\end{array}$ & $\begin{array}{c}\text { GREFI } \\
\text { EFACENCY } \\
\mathbf{y}\end{array}$ \\
\hline \multirow{6}{*}{ A } & \multirow{6}{*}{$\begin{array}{l}\text { Public Spaces With Plenty of Green } \\
\text { Area }\end{array}$} & Neighborhood Parks & + & As & 9 & $x$ & & & & \multirow{6}{*}{100} \\
\hline & & Distnct Parks & + & $\mathrm{Az}$ & 9 & $x$ & & & & \\
\hline & & Cty Parks & + & $\mathrm{Aa}$ & 9 & $x$ & & & & \\
\hline & & Botanic Gardens & + & As & 8 & $x$ & & & & \\
\hline & & State Woods & + & As & 8 & $x$ & & & & \\
\hline & & Wooded Aveas & + & $\mathrm{As}$ & 8 & $x$ & & & & \\
\hline \multirow{5}{*}{$\mathbf{B}$} & \multirow{5}{*}{$\begin{array}{l}\text { Spaces with Plenty of Green } \\
\text { Without Public Usage }\end{array}$} & Miltary Green Areas & - & B: & 7 & & $\mathrm{x}$ & & & \multirow{5}{*}{75} \\
\hline & & Dwellings and Other Buildings Gardens & - & $\mathrm{B}_{2}$ & 7 & & $\mathrm{x}$ & & & \\
\hline & & Refüges & - & Ba & 7 & & $\mathrm{x}$ & & & \\
\hline & & Private Woods & - & $\mathrm{B} 4$ & 6 & & $\mathrm{x}$ & & & \\
\hline & & Consulales Gardens & - & $\mathrm{B} 5$ & 6 & & $\mathrm{x}$ & & & \\
\hline \multirow{6}{*}{ c } & \multirow{6}{*}{$\begin{array}{l}\text { Public Spaces with Partial Green } \\
\text { Areas }\end{array}$} & Cemeteries & + & $\mathrm{C}:$ & 5 & & & $x$ & & \multirow{6}{*}{50} \\
\hline & & Squares and Pedestrians Areas & + & $\mathrm{C}_{2}$ & 5 & & & $x$ & & \\
\hline & & Playgrounds & + & $\mathrm{Ca}$ & 5 & & & $x$ & & \\
\hline & & Outdoor Market Places & + & $\mathrm{C}_{4}$ & 4 & & & $x$ & & \\
\hline & & Public Teahouse & + & $\mathrm{C}_{5}$ & 4 & & & $x$ & & \\
\hline & & Public Amusements and Themeparks & + & $\mathrm{C}_{\mathrm{A}}$ & 4 & & & $x$ & & \\
\hline \multirow{7}{*}{ D } & \multirow{7}{*}{$\begin{array}{l}\text { Rekreational Open Spaces with } \\
\text { Littla Green Aveas }\end{array}$} & Prate Teahouse & - & $\mathrm{D}_{1}$ & 3 & & & & $\mathrm{x}$ & \multirow{7}{*}{25} \\
\hline & & Public Oudfoor Water Sports Areas & + & $\mathrm{D}_{2}$ & 3 & & & & $\mathrm{x}$ & \\
\hline & & Public Volleyball, Basketball,Tennis Areas & + & $\mathrm{D}_{3}$ & 3 & & & & $\mathrm{x}$ & \\
\hline & & Private Amusement ve Themeparks & - & $\mathrm{D}_{4}$ & 3 & & & & $\mathrm{x}$ & \\
\hline & & Private Volleyoall,Basketball,Tennis Areas & - & $\mathrm{D}_{5}$ & 2 & & & & $\mathrm{x}$ & \\
\hline & & Privale Outdoor Water Sports Areas & - & $\mathrm{D}_{9}$ & 2 & & & & $\mathrm{x}$ & \\
\hline & & Stadiums & + & $\mathrm{D}_{7}$ & 2 & & & & $\bar{x}$ & \\
\hline
\end{tabular}


Table 3:-Efficiency Percentage of Green Areas in the City.

\begin{tabular}{|c|c|c|c|c|c|c|c|c|c|c|}
\hline & QUALITY & GREEN AREAS IN THE CITY & $\begin{array}{l}\text { WITHIN } \\
\text { STANDART }\end{array}$ & $\begin{array}{c}\text { CODE } \\
\text { NO }\end{array}$ & $\begin{array}{l}\text { POSTTME } \\
\text { FACTOR } \\
\text { NUMBER } \\
\end{array}$ & $\begin{array}{l}\text { L. DEGREE } \\
\text { GREEN } \\
\text { AREAS } \\
\end{array}$ & $\begin{array}{l}\text { IL. DEGREE } \\
\text { GREEN } \\
\text { AREAS } \\
\end{array}$ & $\begin{array}{l}\text { II. DEGREE } \\
\text { GREEN } \\
\text { AREAS } \\
\end{array}$ & \begin{tabular}{|l|} 
N. DEGREE \\
GREEN \\
AREAS \\
\end{tabular} & $\begin{array}{c}\text { GREEN } \\
\text { EFFICIENC } \\
\text { Y\% } \\
\end{array}$ \\
\hline \multirow{9}{*}{$\mathrm{E}$} & \multirow{9}{*}{$\begin{array}{l}\text { Public Spaces with Plenty of } \\
\text { Green Areas }\end{array}$} & National Parks & + & $E_{1}$ & 9 & $\mathrm{x}$ & & & & \multirow{9}{*}{100} \\
\hline & & Regional Parks & + & $E_{2}$ & 9 & $\mathrm{x}$ & & & & \\
\hline & & \begin{tabular}{|l|} 
Nature Parks \\
\end{tabular} & + & $E_{3}$ & 9 & $\mathrm{x}$ & & & & \\
\hline & & Roadside Parks & + & $E_{4}$ & 9 & $\mathrm{x}$ & & & & \\
\hline & & State Woods & + & $E_{5}$ & 8 & $x$ & & & & \\
\hline & & Arboretums & + & $E_{6}$ & 8 & $\mathrm{x}$ & & & & \\
\hline & & Botanic Gardens & + & $E_{7}$ & 8 & $\mathrm{x}$ & & & & \\
\hline & & Wooded Areas & + & $\mathrm{Es}_{8}$ & 8 & $\mathrm{x}$ & & & & \\
\hline & & State Forests & + & $E_{9}$ & 8 & $\mathrm{x}$ & & & & \\
\hline \multirow{11}{*}{$\mathbf{F}$} & \multirow{11}{*}{$\begin{array}{l}\text { Public Green Spaces Ladking } \\
\text { Usability of Green Tissue }\end{array}$} & Picnic Areas & + & $\mathrm{F}_{1}$ & 7 & & $\mathrm{x}$ & & & \multirow{11}{*}{75} \\
\hline & & Climbing and Hunting Areas & + & $\mathrm{F}_{2}$ & 7 & & $\mathrm{x}$ & & & \\
\hline & & Zoos & + & $\mathrm{F}_{3}$ & 7 & & $\mathrm{x}$ & & & \\
\hline & & \begin{tabular}{|l|} 
Public Plant Nursery \\
\end{tabular} & + & $\mathrm{F}_{4}$ & 7 & & $\mathrm{x}$ & & & \\
\hline & & Vineyards and Orchards & - & $\mathrm{F}_{5}$ & 7 & & $\mathrm{x}$ & & & \\
\hline & & Apple Orchards and Olive Groves & - & $\mathrm{F}_{6}$ & 7 & & $\mathrm{x}$ & & & \\
\hline & & Military Green Areas & - & $\mathrm{F}_{7}$ & 7 & & $\mathrm{x}$ & & & \\
\hline & & Refuges & - & $\mathrm{F} s$ & 7 & & $\mathrm{x}$ & & & \\
\hline & & Private Forests & - & $\mathrm{Fg}_{9}$ & 6 & & $\mathrm{x}$ & & & \\
\hline & & Private Woods & - & $F_{10}$ & 6 & & $\mathrm{x}$ & & & \\
\hline & & Archery, Golf, etc. Areas & - & $F_{11}$ & 6 & & $\mathrm{x}$ & & & \\
\hline \multirow{8}{*}{ G } & \multirow{8}{*}{$\begin{array}{l}\text { Green Spaces Lacking of } \\
\text { Usability or Landscape } \\
\text { Contribution }\end{array}$} & Cemeteries & + & $\mathrm{G}_{1}$ & 5 & & & $\mathrm{x}$ & & \multirow{8}{*}{55} \\
\hline & & Kale yards & - & $\mathrm{G}_{2}$ & 4 & & & $\mathrm{x}$ & & \\
\hline & & Crop Fields & - & $\mathrm{G}_{3}$ & 4 & & & $\mathrm{x}$ & & \\
\hline & & \begin{tabular}{|l|} 
Private Plant Nursery \\
\end{tabular} & - & $\mathrm{G}_{4}$ & 4 & & & $\mathrm{x}$ & & \\
\hline & & Fair Areas & + & G5 & 4 & & & $x$ & & \\
\hline & & Beach and Coastal Areas & + & G6 & 4 & & & $\mathrm{x}$ & & \\
\hline & & Public Amusements and Theme Parks & + & $\mathrm{G}_{7}$ & 4 & & & $\mathrm{x}$ & & \\
\hline & & Public Volleyball, Basketball, Tennis Ad & + & $\mathrm{Gs}$ & 4 & & & $\mathrm{x}$ & & \\
\hline \multirow{8}{*}{ H } & \multirow{8}{*}{$\begin{array}{l}\text { Recreational Open Spaces with } \\
\text { Little Green Ladking Landscape } \\
\text { Contribution }\end{array}$} & Outdoor Show Areas & + & $\mathrm{H}_{1}$ & 3 & & & & $\mathrm{x}$ & \multirow{8}{*}{35} \\
\hline & & Stadiums & + & $\mathrm{H}_{2}$ & 3 & & & & $\mathrm{x}$ & \\
\hline & & Horse Racing Tracksand Stud Farms & - & $\mathrm{H}_{3}$ & 3 & & & & $\mathrm{x}$ & \\
\hline & & Public Outdoor Water Sports Areas & + & $\mathrm{H}_{4}$ & 2 & & & & $\mathrm{x}$ & \\
\hline & & Private Amusement, Theme parks & - & $\mathrm{H}_{5}$ & 2 & & & & $\mathrm{x}$ & \\
\hline & & Private Outdoor Water Sports Areas & - & $\mathrm{Hs}$ & 2 & & & & $\mathrm{x}$ & \\
\hline & & Private Volleyball,Basketball,Tennis Arr & - & $\mathrm{H}_{7}$ & 2 & & & & $\mathrm{x}$ & \\
\hline & & \begin{tabular}{|l|} 
Greenhouse Areas \\
\end{tabular} & - & $\mathrm{H}_{8}$ & 2 & & & & $\mathrm{x}$ & \\
\hline
\end{tabular}

Common characteristic groups of "green areas in city":

1. Public Spaces with plenty of green areas

2. Spaces with plenty of green areas but without public usage

3. Public spaces with partial green areas

4. Sports, entertainment and rest areas with little green areas

Common characteristic groups of "green areas around the city":

1. Public spaces with plenty of green areas

2. Green areas lacking an adequate level of usability or green tissue

3. Green areas lacking usability and landscape contribution

4. Recreational open spaces with little green area lacking landscape contribution

The breakdown of green areas that the groups of characteristics contain are shown in Tables 2 and 3 with the positive factor numbers. If a grading is prepared from green area-specific groups with high factor numbers to green area-specific groups with low factor numbers:

1. Group $A$ is green areas in city with positive factor numbers 9 and eight as 1 st degree

2. Group B is green areas in city with positive factor numbers 7 and six as 2 nd degree

3. Group $\mathrm{C}$ is green areas in city with positive factor numbers 5 and four as 3 rd degree

4. Group D is green areas in city with positive factor numbers 3 and two as 4 th degree 


\section{In the same way:-}

1. Group $\mathrm{E}$ is green areas surrounding the city with positive factor numbers 9 and eight as 1 st degree

2. Group $F$ is green areas surrounding the city with positive factor numbers 7 and six as 2 nd degree

3. Group $\mathrm{G}$ is green areas surrounding the city with positive factor numbers 5 and four as 3 rd degree

4. Group $\mathrm{H}$ is green areas surrounding the city with positive factor numbers 3 and two as 4 th degree

5. These determinations above are accepted grading for green areas in and around the city.

Assuming that the accepted performances of the highest degree green areas will be the highest considering the green areas; a "Green Efficiency Coefficient" should be defined reflecting the performances of the characteristic groups of all green areas with certain hierarchy and percentage ratios. In short, "Green Efficiency Coefficient" can be explained as the expected performance degree from green areas and determined by the percentage ratio. This coefficient is revealed as parallel to the green area gradation determined according to the numbers of positive factor describe in the second section. "Green Efficiency Coefficients," are shown in Tables 2 and three separately for green area groups in and around the city.

It can be clearly seen that the green areas, both in and around the city, four different green area hierarchy is valid. In this case, green efficiency coefficient for the first-degree green areas (highest factor number being 8 and 9) may be accepted as \% 100.Then the average unit ratio per each factor number can be calculated as $11,76(100 / 8,5)$. When this value is multiplied by the average positive factor numbers of the $2 \mathrm{nd}$, third and 4th-degree green areas; the green efficiency coefficients can be obtained. To show it more clearly:

1. The green efficiency coefficient is approximately $\% 29(11,76 \times 2,5)$ for fourth-degree green areas with positive factor number 2 and 3.

2. The green efficiency coefficient is approximately $\% 52(11,76 \times 4,5)$ for third-degree green areas with positive factor number 4 and 5 .

3. The green efficiency coefficient is approximately $\% 76(11,76 \times 6,5)$ for second-degree green areas with positive factor number 6 and 7.

These values can be considered as $\% 25, \% 50$, and $\% 75$ for easy calculation in practice.

As the result, with respect to the above determinations, the green efficiency coefficients in and around the cities, starting from the highest to the lowest can be categorized as follows: (see Table 2 and 3).

1. $\% 100$ for first-degree green areas

2. $\% 75$ for second-degree green areas

3. $\% 50$ for third-degree green areas

4. $\% 25$ for fourth-degree green areas

Figures 4 and 5 indicate the distributions of green area types, classified in and around the city; showing the effective values of "Green Efficiency Coefficient " with respect to the green area characteristics. 


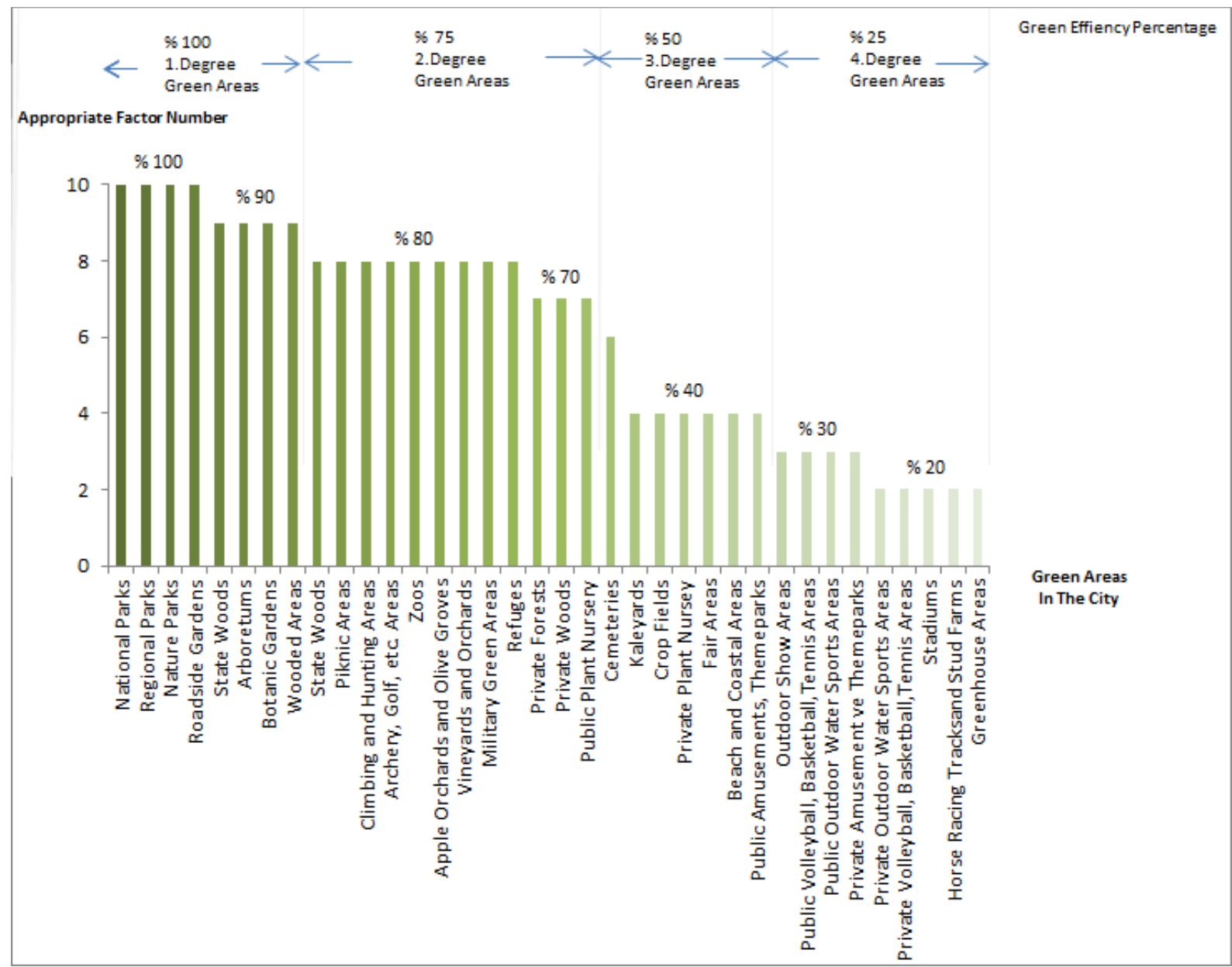

Figure 4:- Green Areas Efficiency Percentage Distribution Graph in the City based on Factor Numbers. 


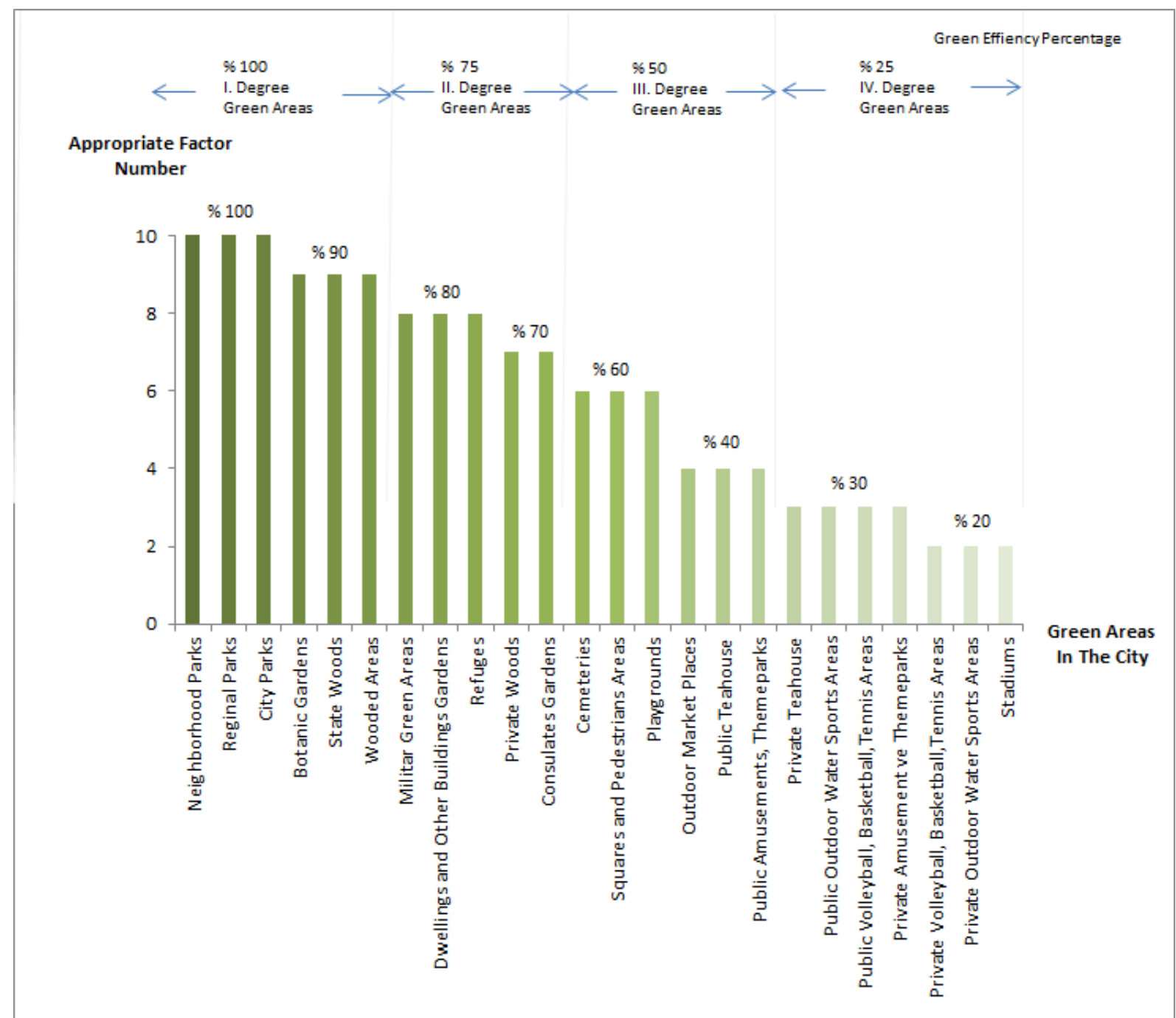

Figure 5:- Green Areas Efficiency Percentage Distribution Graph around the City based on Factor Numbers.

\section{Determination of Effective Green Area Sizes:-}

As explained above, the sums of green area sizes of 1st, 2nd, third and 4th degrees are the sums of A+ B+ C+ D in the cities and $\mathrm{E}+\mathrm{F}+\mathrm{G}+\mathrm{H}$ around the cities. Their actual openings in and around the city can be seen in Tables 2 and 3 .

\section{In the city:-}

1. Public Areas with Plenty of Green: $A=A_{1}+A_{2}+A_{3}+A_{4}+A_{5}+A_{6}($ Green Efficiency Coefficient :\%100)

2. Areas with Plenty of Green but Without Public Usage: $B=B_{1}+B_{2}+B_{3}+B_{4+} B_{5}$ ( G.E.C : \% 75 )

3. Public Areas with Partial Green:C $=\mathrm{C}_{1}+\mathrm{C}_{2}+\mathrm{C}_{3}+\mathrm{C}_{4}+\mathrm{C}_{5}+\mathrm{C}_{6}$ ( G.E.C : \% 50 )

4. Recreational Open Areas with Little Green:D $=D_{1}+D_{2}+D_{3}+D_{4}+D_{5}+D_{6}+D_{7}$ ( G.E.C : \% 25 )

\section{Around the city:-}

1. Green Areas with Plenty of Green and High Usage:E $=E_{1}+E_{2}+E_{3}+E_{4}+E_{5}+E_{6}+E_{7}+E_{8}$ ( Green Efficiency Coefficient: \% 100)

2. Public Green Areas Lacking an AdaquateLevel of Usability or Green Tissue:F $=F_{1}+F_{2}+F_{3}+F_{4}+F_{5}+F_{6}+F_{7}$ $+\mathrm{F}_{8}+\mathrm{F}_{9}+\mathrm{F}_{10}+\mathrm{F}_{11}+\mathrm{F}_{12}$ ( G.E.C: $\% 75$ )

3. Green Areas Lacking Usability and Lanscape Contribution: $\mathrm{G}=\mathrm{G}_{1}+\mathrm{G}_{2}+\mathrm{G}_{3}+\mathrm{G}_{4}+\mathrm{G}_{5}+\mathrm{G}_{6}+\mathrm{G}_{7}$ ( G.E.C: \% $50)$

4. Recreational Open Areas with Little Green and Lacking Landscape Contribution : $\mathrm{H}=\mathrm{H}_{1}+\mathrm{H}_{2}+\mathrm{H}_{3}+\mathrm{H}_{4}+\mathrm{H}_{5}$ $+\mathrm{H}_{6}+\mathrm{H}_{7}+\mathrm{H}_{8}+\mathrm{H}_{9}$ ( G.E.C : \% 25 ) 
If all of these green area sizes should be transformed into effective green area sizes, each one of the green area size in green area group must be multiplied by the above-mentioned " Green Efficient Coefficient."

In this case, the sizes of effective green areas in and around the city are formulated as follows:

Total effective green area sizes in city $=\mathrm{A}+0,75 \mathrm{~B}+0,50 \mathrm{C}+0,25 \mathrm{D}$

Total effective green area sizes around the city $=\mathrm{E}+0,75 \mathrm{~F}+0,50 \mathrm{G}+0,25 \mathrm{H}$

\section{Formulation of Green Area Standart by Effectıve Green Area Method:-}

Green area standard is explained as the green area size per capita in the planned area. The value that this standard will get shows differences depending on the cities and countries according to the planning conditions and applications. The definition of this standard value and the problems in reaching the mentioned standard value are detailly explained in Chapter 2.

In this article, the standard value determined as the green area size per capita in planning is not noticed. Highlighted topic is the way to calculate it by the effective green area view in fact. For this aim, a new calculation system has been brought as "Effective Green Area Method". The "green area size capita" used as "green area standard" can be formulated below as "effective green area size per capita" as explained above considering effective green area sizes.

Effective Green Area Standard (E.G.A.S) = Green Area Size x Green Efficiency Coefficient / Population Therefore, the formulas of the effective green area standard per person are obtained by dividing the effective green area sizes in and around the city to the population of the planning area, as explained above. Those formulas are below:

$$
\begin{aligned}
& \text { E.G.A.S } S_{\text {in city }}\left(\mathrm{m}^{2} / \text { person }\right)=(\mathrm{A}+0,75 \mathrm{~B}+\mathbf{0 , 5 0} \mathrm{C}+\mathbf{0 , 2 5} \mathrm{D}) / \text { population } \\
& \text { E.G.A.S } \mathrm{S}_{\text {around the city }}(\mathrm{m} 2 / \text { person })=(\mathrm{E}+\mathbf{0 , 7 5} \mathrm{F}+\mathbf{0 , 5 0} \mathrm{G}+\mathbf{0 , 2 5} \mathrm{H}) / \text { population }
\end{aligned}
$$

In reality, generally in urban conception, a green area standard value per person is not used for around the city. The green area types around the city as mentioned in Table 3, are generally found in the green belt surrounding the city. The reason for this is because the green belt around the city is the belt which protects the city. Therefore the green tissue belong this belt is also under protection.

Still, nowadays, considering some mega-cities such as Tokyo, Sydney, and Beijing, there is no success so much for the protection of green belts from activities and construction (Ratcliffe, 1974). Whereas, these areas are green areas where citizens can use for long periods. That is why their efficiency in city life is vital. For this reason, considering their positive effect on the city, their necessity can not be denied. So, if a standard value should be used in the concept of the green areas around the city; the green area sizes that will be used in the standard calculation, must be calculated by the effective green area method, just like the green areas in the city.

Determined formulas (1) and (2) are very flexible in adding or extracting, various green area types to planning as can be understood by the formation of the effective green area method as well. The important main idea is into which group the mentioned green area type should be included.

\section{Evaluation and Discussion:-}

Concerning the planning discipline, areas with a green character belonging to private possession are not included in determined green area standard per person. The reason is that considering both the construction regulations and the urban planning discipline; the green areas in the city are accepted as public owned places assigned for general services (Gül, 2001).

On the contrary in this article, private green areas especially in the city such as houses and establishment gardens (Erkun, 1999) with expropriation obligation factor negative; are included into green areas when calculating the efficient green area standard. Because these mentioned areas own positive values for different characteristics other than the "expropriation obligation" factor. For that reason, even though they can not completely be used by the public, that kind of green areas; have the green area performance of their green efficiency coefficient ratio determined by this method. 
Also, the areas of private status like the military green areas and green areas of foreign representatives; although closed for public use; are \%100 include to the determined green area standard conventionally used. The efficient green area calculation explained in this article eliminates the contradiction by including such areas into the total green area by the green efficiency coefficient rate.

In this article, green areas have been grouped according to the green efficiency coefficients that explained above for their benefits to urban. However, in this regard that kind of mistake should not be done like "low green efficiency coefficient" means poor green quality. Because, no matter what type, every kind of green area is essential for urban with its function. That is why all kinds of green areas are not given up in planning. Green efficiency coefficient explained in this paper, reveals the importance of two main factors as the amount of green tissue and opening to public use regarding their benefits to city climate and energy-saving. Therefore, Efficiency Green Area Standard (E.G.A.S) must be used in a sense of efficiency of green control together with green area standard conventionally used.

Consequently, in this article, a more efficient method is proposed to reach the green area standard accepted legally and by discipline in planning. A brand new green area standard value is not determined.

As very well known, all of the green area types do not need to take place in every planning area. Certain green area types can only take place in in the planning area concerning characteristics such as population etc. The emphasis in this article is, determining the weights of green area types regarding opening to public use and green tissue amount shall be included in the standard.

As long as the planned urban settlement area gets large, some of the green areas around the city or almost all just as in the metropolitan areas may stay in the city. Such a case will cause no difference in the calculation; the mentioned green area type will be included in urban green area formula with its green efficiency coefficient.

Therefore the two different effective green area standard formulas suggested in this article can be simplified in practice and transformed into one formula. In this case, the sizes of effective green areas in the standard formula can be calculated as; $\quad(\mathrm{A}+\mathrm{E})+\% 75(\mathrm{~B}+\mathrm{F})+\% 50(\mathrm{C}+\mathrm{G})+\% 25(\mathrm{D}+\mathrm{H})$ and divided by the area population. So, one single standard control can be made as effective green area per person.

Besides, in time, considering the improvements in life conditions such as new green area types and placing green on buildings, green roofs (Werthmann, 2007), etc. innovations can continuously be added. This method is in a structure that enables to determine the green efficiency coefficients of the new types by the determined factors.

This approach, on one side, by including all types of green areas into calculation; enables to increase the standard value of green areas in and around the city above the standard values applied up today. On the other hand, it will be much more useful concerning the performance of the planned green areas.

\section{Conclusions:-}

1. The green area standard that should be obeyed in urban settlement planning depending on the size of the settlement must be divided into two sections being inside the city and around the city if needed.

2. Green areas can be evaluated in six general categories being resting, garden use, entertainment, games and sports, agriculture and private status.

3. Green areas have five main urban benefits being control of ecological balance, prevention of environmental pollution, control of natural disasters, fulfilment of social activities and psychological satisfaction.

4. The more green tissue and being open to public use characteristics; the more suitable are the green areas to urban end environmental benefits.

5. The nine main factors that are effective on the urban and environmental benefits of green areas are determined. These factors are; the obligation of expropriation, low user density, usability, lack of solid ground ratio, be active usage, a variation on heights of plants, low construction density, a plurality of diversity of plants and protection of natural environment impression.

6. Green area groups are evaluated according to the number of positive factors. Consequently being both insides of the city and around the city, four green area groups with varying positive factor numbers are determined. 
7. When calculating the green area standards regarding $\mathrm{m}^{2}$ per person, the sizes of green areas both in and around the city should be calculating considering the "green efficiency coefficients" that determine the green area performances.

8. The green efficiency coefficients of green area types are determined depending on the bigness of the positive factor numbers explained in this article. If the positive factor number increases, the green efficiency coefficient also increases.

9. Green area sizes in plans can be transformed into "effective green area sizes" if multiplied by green efficiency coefficients. In city planning divided the total of effective green area sizes pay the population of the plan we find the size of effective green area per person. Of course, it is a must to control if this value in compliance with the green area standard value conventionally used of the plan.

10. "Effective Green Area Standard" formulas have been developed as (1) and (2) for in and around the city. These formulas are improved by reducing the green areas coded with A, B,C,D,E,F,G and H shown in Table (1)and (2), into effective green area sizes by their green efficiency coefficients.

11. As explained in the "evaluation and discussion" section, if there is no need for distinction of in and around the city, this mentioned "Efficient Green Area Standard" formulas can be reduced to one single formula as follow:

12. E.G.A.S $=[(\mathrm{A}+\mathrm{E})+\% 75(\mathrm{~B}+\mathrm{F})+\% 50(\mathrm{C}+\mathrm{G})+\% 25(\mathrm{D}+\mathrm{H})] /$ population of plan

13. Effective green size formula can be generalized as shown below:

14. E.G.A = Green Area Size X Green Efficiency Coefficient

\section{References:-}

1. Çetiner, A. 1979.Şehir planlamasında Çalışma Yöntemleri ve Iffade Teknikleri, İstanbul, İTÜ Mimarlık Fakültesi, Bask1 Atölyesi, s.235-236

2. Erkün, S. 1999.Türk İmar Hukukunun Ana Çizgileri, İstanbul, Yapı Endüstri Merkezi Yayınları, Acar Matbaacılık A.Ş., s. 41-42

3. Germann-Chiari C, Seeland K. 2002.Are Urban Green Spaces Optimally Distributed to Act As Places For Social Integration? Results of a Geographical Information System (GIS) Approach for Urban Forestry Research, Forest Policy and Economics 6:3-13

4. Gül, A. 2001.Kentsel Açık- Yeşil Alanlar ve Isparta Kenti Örneğinde İncelenmesi, Isparta, Süleyman Demirel Üniversitesi,Orman Fakültesi Dergisi, Seri A, Sayı 2, ISSN:1302-7085, pp.27-48.

5. Karagüler, S. 1993. "Yapılaşma Sonucu Yeşil Alan Azalmasındaki Sakıncaların Giderilmesi İçin Binalarda Bitki Kullanımları”, Doktora Tezi, İstanbul,İTÜ, Fen Bilimleri Enstitüsü, s.33-36.

6. Karagüler, S. 2004. "Kent Planlamasında Yeşil Alan Gereksinimi”, Mimarist Dergisi, Sayı 11, s. 103.

7. Lyle, T. J. 1985. "Design for Human Ecosystem: Landscape, Land Use, and Natural Resources", Van Nostrand Reinhold, New York.

8. Mira, O. 2013. "Houses Think Green”, Instituto Monsa de Ediciones,S.A. Intro.

9. Öztürk, B. 2004.Kentsel ve Açık Yeşil Alan Sistemi Oluşturulması, Ankara, Ankara Üniversitesi, Fen Bilimleri Enstitüsü, Peyzaj Anabilim Dalı.

10. Schipperijn, J., Stigsdotter, U.K., Randrup, T.B.,Troelsen, J. 2010a."Influences on the Use of Urban Green Spaces- A case study in Odense, Denmark",Elsevier,Urban Forestry \& Urban Greening 9: p.27.

11. Schipperijn, J. et al. 2010b. "Factors influencing the use of green space results from a Danish national representative survey”, Landscape and Urban Planning, Vol. 95, No. 3, 2010, p. 130-137

12. Ratcliffe, J. 1974.An Introduction to Town and Country Planning,London, The Anchor Press Ltd, s. 7-10.

13. Voss, K.,Musall, E. 2013.Net Zero Energy Buildings, EnOB, Detail Green Books, GmbH \& Co. KG, Munich. p.139.

14. Wang, H.B. et al. 2014.Past land use decisions and socioeconomic factors influence urban greenbelt development: a case study of Shanghai, China,Landscape Ecology, 10/2014; DOI: 10.1007/s10980-014-0104-1

15. Werthmann, C. 2007.Green Roof - A case Study, PartI: Essay, The Reclamation of Roofs, New York, Princeton Architectureal Press, s.18.

16. Yıldızcı, A.C. 1982. "Kentsel Yeşil Alan Planlaması ve İstanbul Örneği”, Doçentlik Tezi, İstanbul, İTÜ Mimarlık Fakültesi Matbaası. 